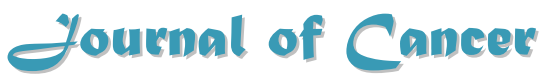

2010; 1:63-69

Research Paper

(C) Ivyspring International Publisher. All rights reserved

\title{
A seemingly most effective target for early detection and intervention of prostate tumor invasion
}

\section{Yan-gao Man ${ }^{\bowtie}$}

Armed Forces Institute of Pathology and American Registry of Pathology, Washington DC, USA, and Jilin University, China

$\triangle$ Corresponding author: Yan-gao Man, MD., PhD., Director of Gynecologic and Breast Research Laboratory, Department of Gynecologic and Breast Pathology, Armed Forces Institute of Pathology and American Registry of Pathology. Tel: 202-782-1612; Fax: 202-782-3939; E-mail: man@afip.osd.mil

Published: 2010.06.24

\begin{abstract}
This commentary proposes that budding tumor cell projections from focally disrupted tumor capsules represent a most effective target for early detection and intervention of prostate tumor invasion. The rationale, supporting data, and clinical applications of the hypothesis are discussed.
\end{abstract}

Key words: Prostate cancer; Invasion; Early detection; Basal cells; Tumor cell budding; Stem cells

\section{The structural features of the human pros- tate}

The normal and pre-invasive prostate tumor epithelium, which is the histological origin of over $80 \%$ of the human prostate malignancies, is physically separated from the stroma by the basal cells and basement membrane. Basal cells are joined by intercellular junctions and cell surface adhesion molecules, forming a largely continuous sheet encircling epithelial cells [1-2]. The basement membrane is composed of type IV collagen, laminins, and other molecules, forming a continuous lining surrounding the basal cell layer [3-4] (Fig 1). Together, the basal cell layer and the basement membrane constitute a morphologically distinct capsule, which is a permanent structural element largely independent of hormonal regulation and the host's bio-physiological condition [1-4]. The epithelial cells are held in place by intercellular junctions and cell surface adhesion molecules (Fig 2). The epithelium is normally devoid of blood vessels and lymphatic ducts and totally relies on the stroma for its basic needs. Due to these structural relationships, the physical and functional status of the tumor capsule significantly impacts the biological behavior of the epithelial cells, and the disruption of the tumor capsule is a pre-requisite for prostate tumor invasion and metastasis.

\section{Focal basal cell alterations and disruptions in tumor capsules}

Prostate tumor invasion is believed to be a multistage process, progressing sequentially from normal to hyperplasia, to prostatic intraepithelial neoplasia (PIN), and to invasion [5-8]. Progression from PIN to invasion is believed to be triggered by overproduction of proteolytic enzymes primarily by cancer cells, which cause degradation of the tumor capsule [9-10]. These theories are consistent with experimental data from tissue cultures or animal models, but they are hard to reconcile with four critical facts: (a). previous studies have revealed that some healthy men between 19 and 29 years old demonstrated a spectrum of proliferative abnormalities in the prostate, including atypical hyperplasia, dysplasia, and incipient adenocarcinoma [11-13], (b) Recent studies have detected a DNA phenotype that is identical to the DNA structure of invasive prostate cancer in certain healthy men, and in normal prostate tissues adjacent to prostate cancer [14-17], (c) a majority of PIN express high le- 
vels of proteolytic enzymes, but only about $30 \%$ of untreated PIN progress to invasive lesions during patients' lifetime [18-21], and (d) results from worldwide human clinical trials with a wide variety of proteolytic enzyme specific inhibitors to treat or prevent tumor invasion have been very disappointing $[22,23]$. Together, these suggest that alternative mechanism(s) may exist for prostate tumor invasion.

A number of clinic tests, including the measurement of the serum level of prostate specific antigen (PSA), MRI, and gene expression profiling, are increasingly used in the clinic, whereas none of those could predict which of the PIN lesions will progress [24-29]. The only established approach to monitor PIN progression is repeat biopsy [25-29], which is costly and painful. Since over $90 \%$ of prostate cancer related mortality result from invasion- related illnesses, and the incidence of PIN could be up to $16.5 \%-25 \%$ in routine or ultrasound guided prostate biopsies [25-29], there is an urgent need to uncover the intrinsic mechanism of tumor invasion, and to develop novel approaches to identify the specific precursor of invasive prostate lesions.

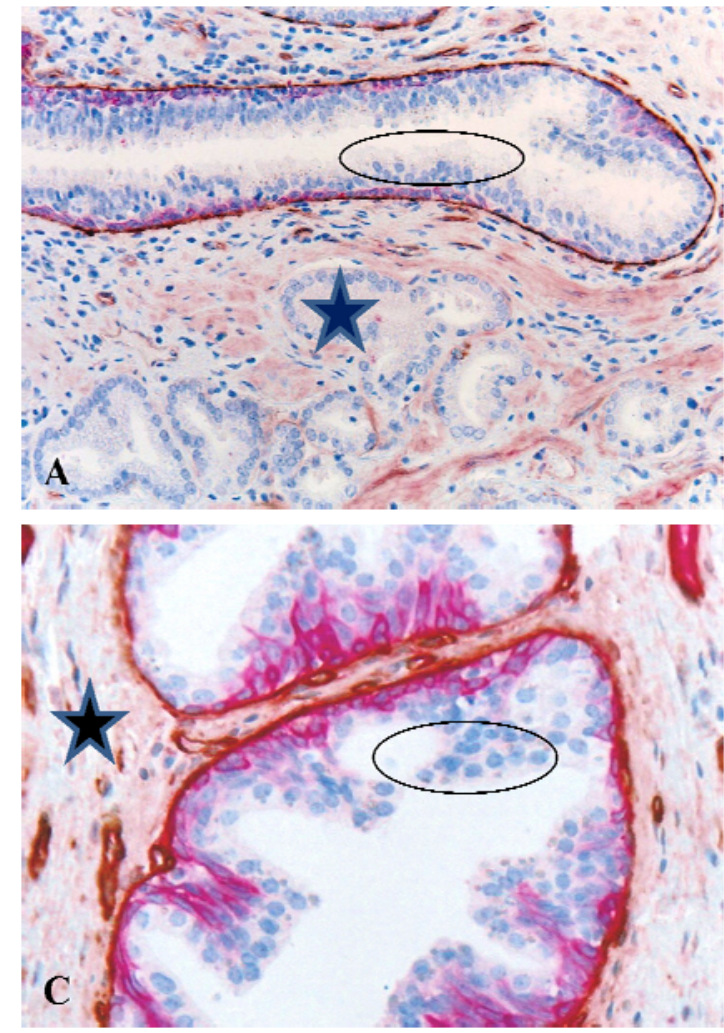

Promoted by the fact that the basal cell layer is the sole source of tumor suppressor p63 and maspin in prostate [31-33], and that the absence of the basal cell layers is one of the most distinct morphological signs of invasive cancers, our resent studies have attempted to identify the early signs of tumor capsule disruptions. Our initial study examined the physical integrity of basal cell layers in 50 patients with co-existing pre-invasive and invasive prostate tumors. Of 2,047 ducts and acini examined, 197 were found to harbor focal disruptions (the absence of basal cells resulting in a gap greater than the combined size of at least 3 basal cells) in the tumor capsule. The frequency of focal tumor capsule disruptions varied from none in $22(44 \%)$ cases to over $1 / 3$ of the ducts or acini with focal disruptions in 17 (34\%) cases [34-38].

Compared to their non-disrupted counterparts, focally disrupted tumor capsules displayed a number of unique alterations, including a significantly lower proliferation index and p63 expression, but a significantly higher frequency of degeneration, apoptosis and infiltration of leukocytes, which are generally located at or near focally disrupted tumor capsules (Fig 3d).

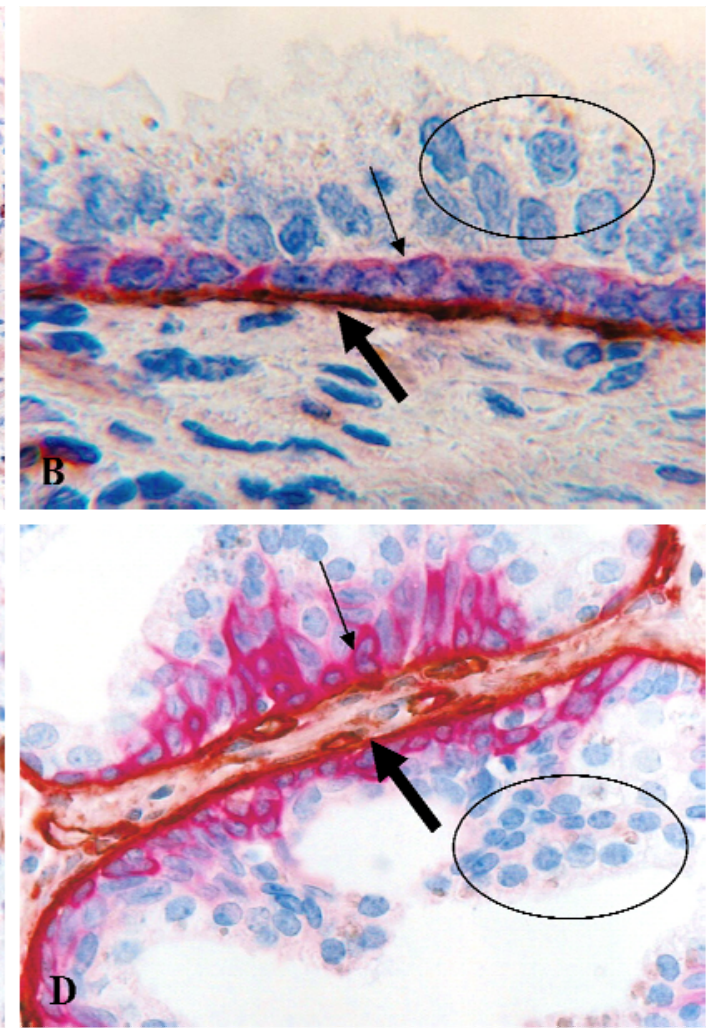

Fig I. Structural relationships among the prostate epithelium, basal cell layer, basement membrane, and stroma. Human prostate sections were double immunostained for cytokeratin 34BEI2 (red) and collagen IV (brown). Circles identify epithelial cells. Starts identify the stroma. Thin arrows identify the basal cell layer. Thick arrows identify the basement membrane. A and C: I50X. B and D: a higher magnification (400X) of A and C, respectively. 


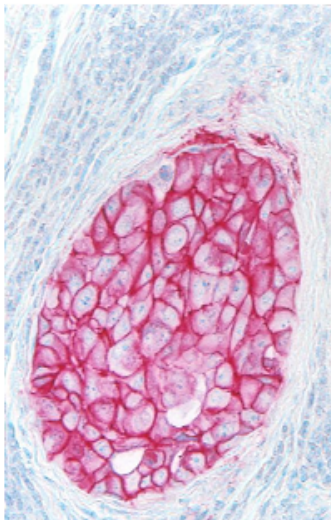

A

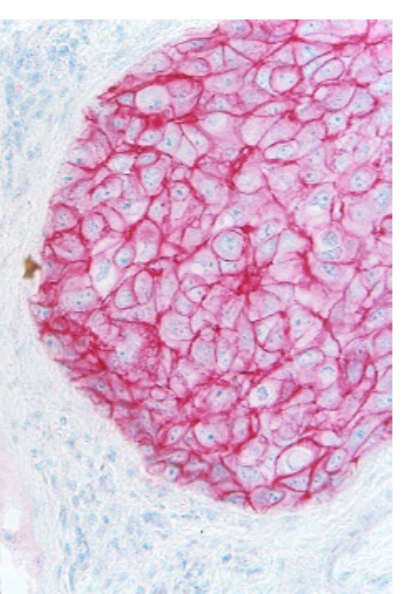

Fig 2. E-cadherin expression in epithelial cells. Sections were immunostained for cell surface adhesion molecule E-cadherin. Note that both the pre-invasive and invasive cancer cells (circle) show strong E-cadherin expression, and the edges of pre-invasive tumors are smooth without budding cells. 150X.

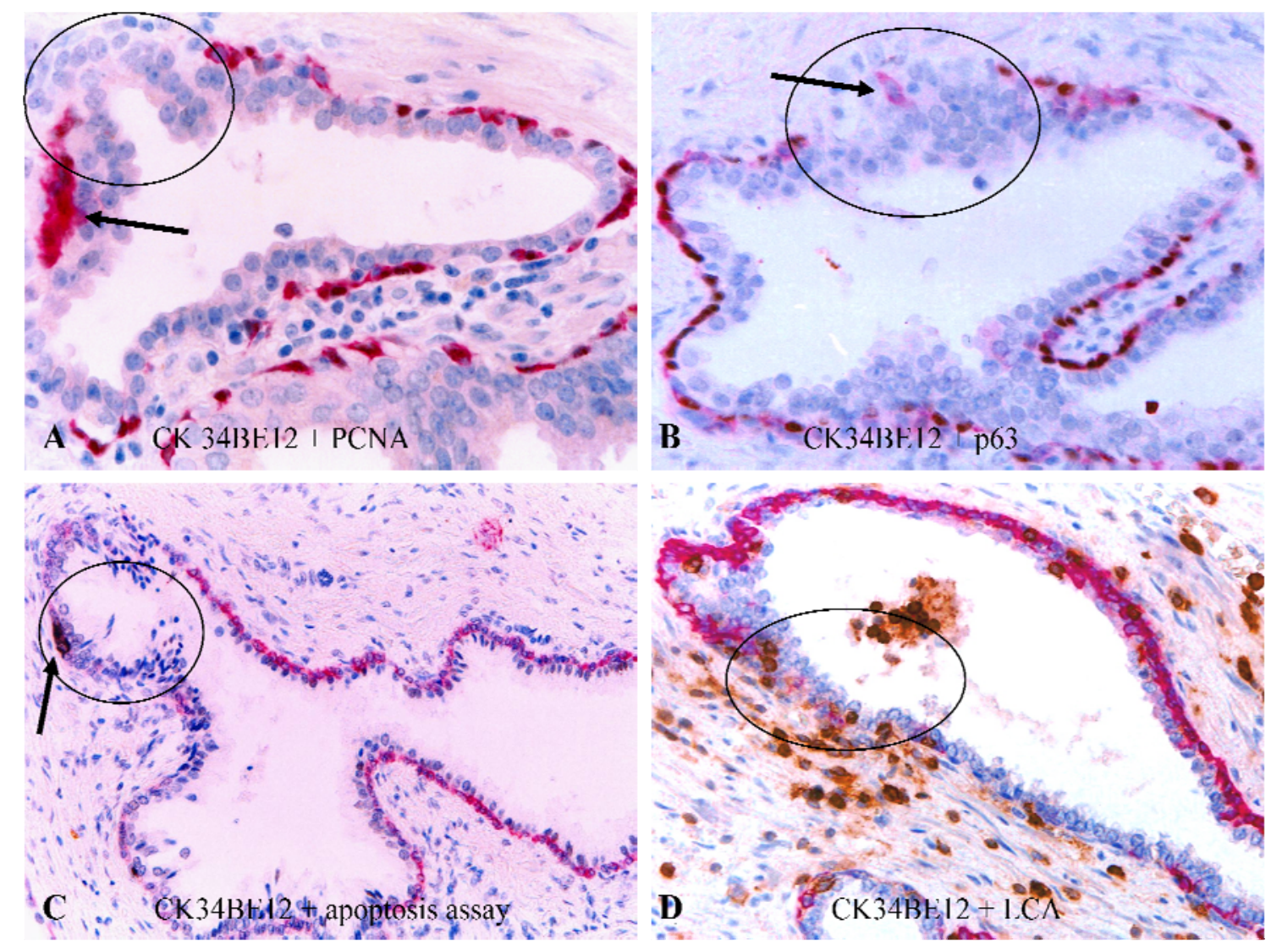

Fig 3. Focal disruptions in tumor capsules. Human prostate sections were double immunostained with different markers. Circles identify focal disruptions in the tumor capsules. Arrows identify degenerated (A), isolated (B), and apoptotic (C) basal cells. Note that most leukocytes (brown particle-like structures) are located at or near focally disrupted capsules. 200X.

\section{Tumor cell budding from focally disrupted tumor capsules}

Focal disruptions in the tumor capsule appear to significantly impact the morphological and biological presentations of associated epithelial cells. Although most focal tumor capsule disruptions were seen in PIN, a subset of normal- and hyperplastic-appearing ducts and acini also showed focal disruptions in their capsules. As shown in Fig 4, epithelial cells overlying focally disrupted capsules of two morphologically normal appearing ducts are arranged as finger- or 
tongue-like projections budding from focally disrupted capsules. Budding cell projections often punctured deep into the stroma and were morphologically indistinguishable from invasive cancer cells (Fig 4). A majority of epithelial structures with budding cell projections were adjacent to invasive lesions and all budding cells from the same or different cases shared s similar morphological and immunohisto-
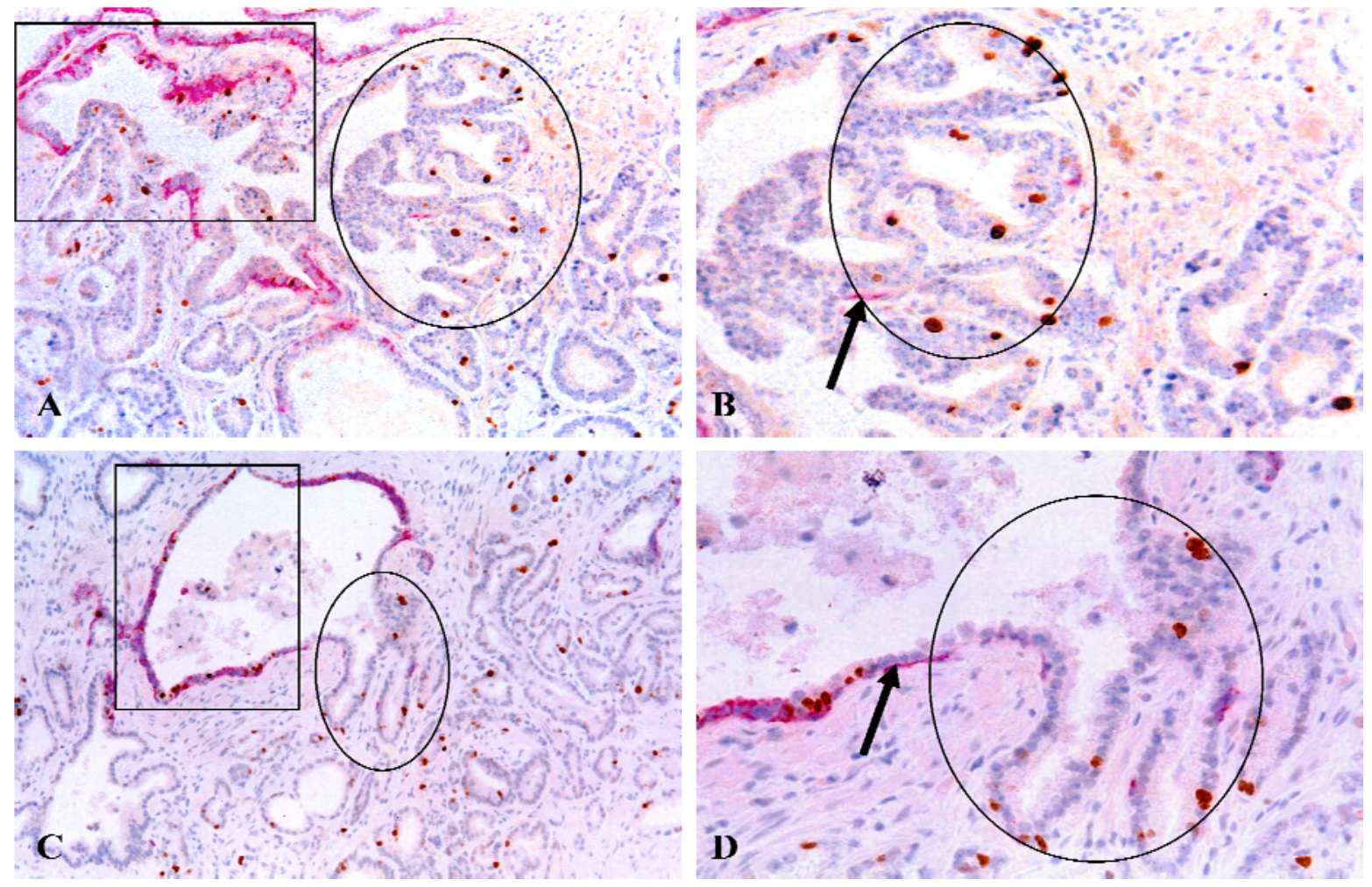

Fig 4. Tumor cell budding from focally disrupted tumor capsules. Human prostate tumor tissue sections were double immunostained for CK34BEI2 (red) and Ki-67 (brown). Circles identify budding tumor cell projections. Squares identify normal appearing prostate ducts in which the budding cell projections are originated. Arrows identify basal cells. A\&C: I00X. B\&D: 300X.
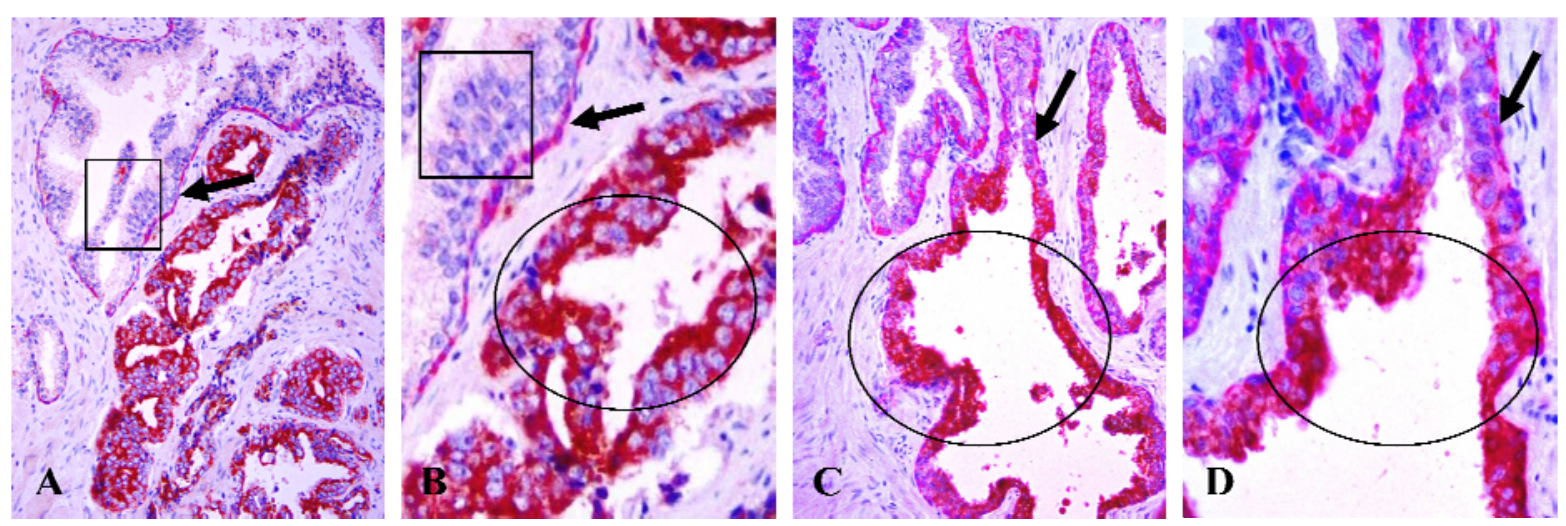

Fig 5. Expression of malignancy-associated molecules. Human prostate tumor sections were double immunostained for CK34BEI2 (red) and AMACR (A-B; brown) or PSA (C-D; brown). Circles identify budding cell projections with AMACR or PSA expression. Squares identify morphologically similar cells without the expression of AMACR or PSA. Arrows identify residual basal cell layer. A \& C: I00X. B \& D: a higher magnification (300X) of A\&C, respectively. 

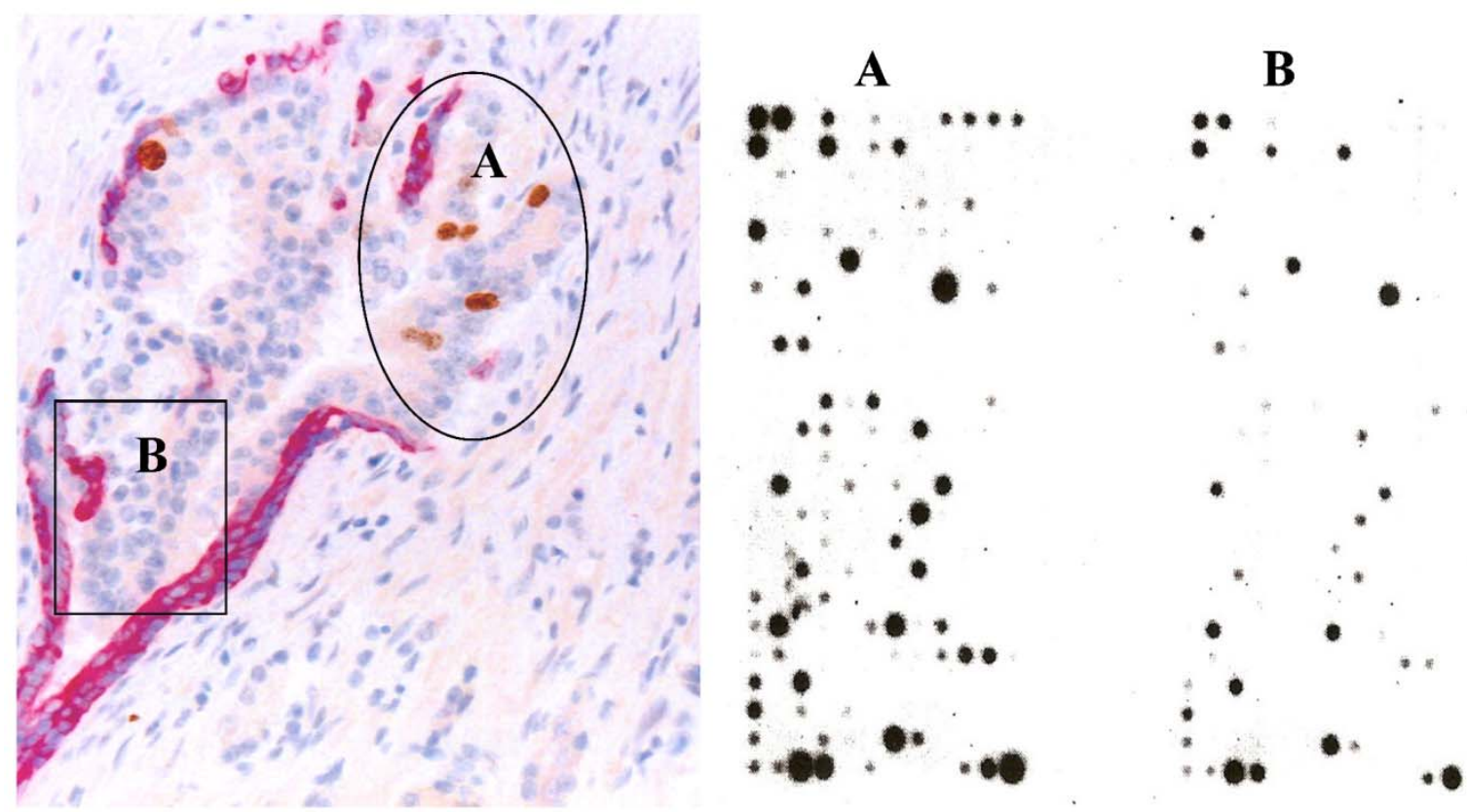

\begin{tabular}{|l|l|l|r|}
\hline & Gene name & \multicolumn{1}{|c|}{ Functional grouping } & Fold change \\
\hline 1 & LIF & Growth factors & 47.37 \\
\hline 2 & MCL1 & Anti-apoptosis & 6.72 \\
\hline 3 & TNFRSF7 & Anti-apoptosis & 7.91 \\
\hline 4 & KIT & Stem cell lineage marker & 5.03 \\
\hline 5 & NCOR2 & Stem cell-related marker & 5.45 \\
\hline 6 & ENG & Endothelial cell marker & 6.38 \\
\hline 7 & ICAM2 & Endothelial cell marker & 12.12 \\
\hline 8 & KRT17 & Epithelial cell marker & 7.15 \\
\hline 9 & ITGA3 & Cell-matrix adhesion & 5.52 \\
\hline 10 & ITGB3 & Cell-matrix adhesion & 7.14 \\
\hline 11 & CCL2 & Chemokine,cytokine, \& receptor & 14.33 \\
\hline 12 & CX3CL1 & Chemokine,cytokine, \& receptor & 6.14 \\
\hline 13 & CCR1 & Chemokine,cytokine, \& receptor & 5.19 \\
\hline 14 & CXCR4 & Chemokine,cytokine, \& receptor & 12.81 \\
\hline 15 & TNFRSF10D & TNF receptor family & 8.20 \\
\hline 16 & TNFRSF12A & TNF receptor family & 5.35 \\
\hline 17 & TNFRSF25 & TNF receptor family & 8.52 \\
\hline 18 & TIMP1 & ECM inhibitor & 5.25 \\
\hline 19 & TIMP3 & ECM inhibitor & 7.87 \\
\hline 20 & MMP26 & Extracellular matrix proteins & -6.94 \\
\hline 21 & IL10 & Interleukin \& receptor & -9.50 \\
\hline 22 & IL12RB2 & Interleukin \& receptor & -7.02 \\
\hline 23 & IL6R & Interleukin \& receptor & -7.24 \\
\hline
\end{tabular}

Fig 6. Differential gene expression between cells overlying focally disrupted tumor capsule (A) and cells within the tumor core (B). Note that budding cells from focally disrupted tumor capsule have a significantly higher expression of invasion and stem cell related genes. 
Gene expression profiling with RNA extracted from microdissected budding cell projections and their adjacent counterparts within the same tumor showed that budding cell projections had a significantly higher expression of stem cell- and tumor invasion-related genes [36] (Fig 6).

\section{Clinical implications of tumor cell budding from focally disrupted tumor capsules}

Our findings of tumor cell budding from focally disrupted prostate tumor capsule are consistent with those of a number of previous studies in human esophageal and colorectal cancers, which detected a similar pattern and frequency of tumor cell budding, and revealed that tumors with budding cells were significantly correlated with invasion, metastasis, and worse prognosis [39-41]. The results of our gene expression profiling are also in line with those of a recent study, which showed that microdissected cells from the periphery and the center of the same ductal carcinoma in situ had a markedly different frequency and pattern in the expression of 22 genes, assessed with Atlas human Cancer 1.2 Arrays containing 1176 known genes [42].

Together, our findings suggest that tumor cell budding from focally disrupted tumor capsules is likely to represent an early sign of tumor invasion. Our findings also suggest that budding tumor cell projections are likely to result from monoclonal proliferation of an activated tumor progenitor or a biologically more aggressive cell clone and represent the direct precursors of invasive prostate lesions. If further validated, budding tumor cell projections from focally disrupted tumor capsules could be considered as a most effective target for early detection and intervention of prostate tumor invasion for three main reasons. First, as focal capsule disruptions with budding cells are also seen in normal- or hyperplastic-appearing ducts and acini, budding cell projections may also represent an early sign of prostate tumor progression that eventually leads to invasion. Thus, the development of more feasible technical approaches to detect focal capsule disruptions with budding epithelial cells in biopsy samples may significantly facilitate differentiation between clinically aggressive and indolent pre-invasive prostate lesions, and also leads to identification of the specific individuals at increased risk to develop invasive prostate cancer. Second, as these budding cell projections are generally surrounded by or adjacent to leukocytes and other stromal cells (as shown in Fig 3), the degradation products from the tumor capsules and the secretory products from the budding cells are likely to enter the blood stream. Thus, the development of a quantitative assay to measure the levels of these molecules in the blood samples could be potentially used as a screen tool to identify the individuals at greater risk to develop invasive prostate cancer. Third, as all budding cell projections within the same or different cases are morphologically and immunohistochemically similar, they are likely to have a very similar molecular profile and also share the same pathway for invasion. Thus, the identification of the shared molecules within these cells could lead to the development of effective therapeutic agents to specifically target all these cells, which could potentially block tumor invasion at the very early stage. However, it is currently difficult, if not impossible, to fully elucidate the molecular and biochemical profiles of these very limited budding cells, due to the lack of sensitive technical approaches.

\section{Acknowledgment}

This study was supported in part by grant BCTR0706983 from The Susan G. Komen Breast Cancer Foundation, grant 2008-02 from US Military Cancer Institute and Henry M. Jackson Foundation, grants DAMD17-01-1-0129 and DAMD17-01-1-0130 from Congressionally Directed Medical Research Programs, grant 2006CB910505 from the Ministry of Chinese Science and Technology Department, and grant 30801176 from The National Natural Science Foundation of China.

The opinions and assertions contained herein represent the personal views of the authors and are not to be construed as official or as representing the views of the Department of the Army or the Department of Defense.

\section{Conflict of Interest}

The author has declared that no conflict of interest exists.

\section{References}

1. Carruba G, Stefano R, Cocciaeliferro L. Intercellular communication and human prostate carcinogenesis. Ann NY Acad Sci 2002; 963:156-168.

2. Goldstein NS, Underhiel J, Roszka N, Neill JS. Cytokeratin 34 beta E-12 immunoreactivity in benign prostate acini. Quantitation, pattern assessment, and electron microscopic study. Am J Clin Pathol 1999; 112:69-74.

3. Bonkhoff H, Wernert N, Dhom G, Remberger K. Basement membranes in fetal, adult normal, hyperplastic and neoplastic human prostate. Virchows Arch A Pathol Anat Histopathol 1991; 418:375-381.

4. Bonkhoff $\mathrm{H}$, Remberger K. Morphogenesis of benign prostatic hyperplasia and prostatic carcinoma. Pathology 1998; 19: 12-20.

5. Bostwick DG. Prospective origins of prostate carcinoma. Prostate intraepithelial neoplasia and atypical adenomatous hyperplasia. Cancer 1996; 78: 330-336. 
6. Haggman MJ, Macoska JA, Wojno KJ, Oesterling JE. The relationship between prostate intraepithelial neoplasia and prostate cancer: critical issues. J Urol 1997; 58:12-22.

7. Bonkhoff H, Remberger K. Differentiation pathways and histogenetic aspects of normal and abnormal prostatic growth: a stem cell model. Prostate 1996; 28: 98-106.

8. Barsky SH, Siegal GP, Jannotta F, Liotta LA. Loss of basement membrane components by invasive tumors but not by the benign counterparts. Lab Invest 1983; 49:140-147.

9. Kosir MA, Wang W, Zukowski KL, Tromp G. Degradation of basement membrane by prostate tumor heparanase. J Surg Res 1999; 81:42-47.

10. Goldfarb RH, Liotta LA. Proteolytic enzymes in cancer invasion and metastasis. Semin Thromb Hemost 1986; 12: 294-307.

11. Gardner WA, Culberson DE. Atrophy and proliferation in the young adult Prostate. J Urol 1987; 137 (1): 53-56.

12. Gardner WA. Hypothesis: Pediatric Origins of Prostate Cancer. Hum Path. 1995; 26:1291-1292.

13. Bennett BD, Gardner WA. Embryonal hyperplasia of the prostate. The Prostate 1985; 3 (7): 411-417.

14. Malins DC, Polissar NL, Su Y, Gardner HS, Gunselman SJ. A new structural analysis of DNA using statistical models of infrared sepctra. Nat Med 1997; 3: 927-930.

15. Malins DC, Johnson PM, Barker EA, Pollssar NL, Wheeler TM, Anderson KM. Cancer-related changes in prostate DNA as men age and early identification of metastasis in prostate tumors. Proc Natl Acad Sci USA 2003; 100: 5401-5406.

16. Malins DC, Anderson KM, Gilman NK, Green VM, Barker EA, Anderson KM. Development of a cancer DNA phenotype prior to tumor formation. Proc Natl Acad Sci Sci USA 2004; 101:10721 $-10725$.

17. Malins DC, Gilman NK, Green VM, Wheeler TM, Barker EA, Anderson KM. A DNA phenotype in healthy prostates, conserved in tumors and adjacent normal cells, implies a relationship to carcinogenesis. Proc Natl Acad Sci USA 2005; 102: 19093-19096.

18. Harvei S, Skijorten FJ, Robsahm TE, Berner A, Tretli S. Is prostatic intraepithelial neoplasi in the transitio/central zone a true presursor of cancer? A long-term retrospective study in Norway. Br J Cancer 1998; 78:46-49.

19. Goeman L, Joniau S, Ponette D, Van der Aa F, Roskams T, Oyen R, Van Poppel H. Is low-grade prostatic intraepithelial neoplasia a risk factor for cancer. Prostate Cancer Prostatic Dis 2003; 6:305-310.

20. Mostofi FK, Sesterhenn IA, Davis CJ Jr. Prostatic intraepithelial neoplasia (PIN): morphological clinical significance. Prostate Suppl 1992; 4:71-77.

21. Kasahara Y, Tsukada Y. New insights and future advances in cancer diagnostics: Limitations of conventional tumor markers. In: Nakarnura RM, Grody WW, Wu JT, Nagle RB, editors. Cancer Diagnostics: Current and future trends. Totowa, NJ: Humanna Press. 2004: 15-26.

22. Coussens LM, Fingleton B, Matrisian LM. Matrix metalloproteinase inhibitors and cancer: trial and tribulations. Science 2002; 295 (5564): 2387-2392.

23. Matrisian LM, Sledge GW Jr, Mohla S. Exacellular proteolysis and cancer: meeting summary and future directions. Cancer Res 2003; 63: 6105-6109.

24. Ashida S, Nakagawa H, Katagiri T, Furihata M, Liizumi M, Anazawa $\mathrm{Y}$, et al. Molecular features of the transition from prostate intraepithelial neoplasia (PIN) to prostate cancer: genome-wide gene-expression profiles of prostate cancers and PINs. Cancer Res 2004; 64:5963-5872.

25. Dawkins HJ, Sellner LN, Turbett GR, Thompson CA, Redmond $\mathrm{SL}$, MeNeal JE, Cohen RJ. Distinction between intraductal carcinoma of the prostate (IDC-P), high-grade dysplasia (PIN), and invasive prostatic adecarcinoma, using molecular markers of cancer progression. Prostate 2000; 44:265-270.

26. Lucia MS, Darke AK, Goodman PJ, La Rosa FG, Parnes HL, Ford LG, et al. Pathologic characteristics of cancers detected in the Prostate Cancer Prevention Trial: implications for prostate cancer detection and chemoprevention. Cancer Prev Res (Phila Pa). 2008 1(3):167-73.

27. Cornud F, Bellin MF, Portalez D. MRI and staging evaluation of prostate cancer. J Radiol. 2006; 87(2 Pt 2):228-243.

28. Haggman MJ, Adolfsson J, Khoury S, Montie JE, Norlen J. Clinical managment of premalignant lesions of the prostate. WHO Collaborative Project and Consensus Conference on Public Health and Clinical Significance of Premalignant Alterations in the Genitourinary Tract. Scand J Urol Nephol Suppl 2000; 205:44-49.

29. Bostwick DG, Qian J, Frankel K. The incidence of high grade prostatic intraepithelial neoplasia in needle biopsies. J Urol 1985; 154: 1791-1784.

30. Signoretti S, Waltregny D, Dilks J, Isaac B, Lin D, Garraway L, et al. p63 is a prostate basal cell marker and is required for prostate development. Am J Pathol 2000; 157:1769-1775.

31. Kurita T, Medina RT, Mills AA, Cunha GR. Role of p63 and basal cells in prostate. Development 2004; 131: 4955-4964.

32. Zou Z, Zhang W, Young D, Gleave MG, Rennie P, Connell R, et al. Maspin expression profile in human prostate cancer (caP) and in vitro induction of maspin expression by androgen ablation. Clin Cancer Res 2002; 8(5):1172-1177.

33. Cher ML, Biliran HR jr, Bhangat S, Meng Y, Che M, Lockett J. Maspin expression inhibits osteolysis, tumor growth, and angiogenesis in animal model of prostate cancer bone metastasis. Proc Natl Acad Sci USA 2003; 100(13): 7847-7852.

34. Man YG, Shen T, Zhao YG, Sang QX. Focal prostate basal cell layer disruptions and leukocyte infiltration are correlated events: A potential mechanism for basal cell layer disruptions and tumor invasion. Cancer Detect Prev 2005; 29: 161-169.

35. Man YG, Zhao CQ, Wang J, XL Chen. A subset of prostate basal cells lacks corresponding phenotypic markers. Pathol Res Pract 2006; 202 (9): 651-662.

36. Man YG and Gardner WA. Focal degeneration of basal cells and the resultant autoimmune- reactions: a novel mechanism for prostate tumor progression and invasion. Med Hypotheses 2008; (70):387-408.

37. Man YG, Gardner WA. Bad seeds produce bad crops: a single step-process of prostate carcinogenesis and Progression. Int J Biol Sci 2008; 4: 246-258.

38. Liu AJ, Wei LX, Gardner WA, Man YG. Correlated alterations in prostate basal cell layer and basement membrane. Int J Biol Sci 2009; 5: 276-285.

39. Miyata H, Yoshioka A, Yamasaki M, Nushijima Y, Takiguchi S, Fujiwara $Y$, et al. Tumor budding in tumor invasive front predicts prognosis and survival of patients with esophageal squamous cell carcinomas receiving neoadjuvant chemotherapy. Cancer 2009; 115(14): 3324-3334.

40. Wang LM, Kevans D, Mulcahy H, O'Sullivan J, Fennelly D, Hyland J, O'Donoghue D, Sheahan K. Tumor budding is a strong and reproducible prognostic marker in T3N0 colorectal cancer. Am J Surg Pathol 2009; 33(1): 134-141.

41. Hart IR. New evidence for tumor embolism as a model of metastasis. J Pathol 2009; 219 (3): 275- 276.

42. Zhu G, Reynolds L, Crnogorac-Jurceic T, Gillett CE, Dublin EA, Marshall JF, et al. Combination of microdissection and microarray analysis to identify gene expression changes between differentially located tumour cells of breast cancer. Oncogene $2003 ; 22: 3742-3748$. 